A.C $\begin{aligned} & \text { Revista de } \\ & \text { Administração } \\ & \text { Contemporânea } \\ & \text { Journal of Contemporary Administration }\end{aligned}$

Editorial

\title{
The Impossibility of Open Science without Otherness and Epistemic Plurality
}

\author{
A Impossibilidade da Ciência Aberta sem Alteridade e Pluralidade \\ Epistêmica
}

Marcelo de Souza Bispo*1,2

\section{ABSTRACT}

My objective in this text is to present a counterpoint to the positivist bias that has dominated the debate on open science and eventually highlight some problems and provide a more plural and inclusive perspective on the subject. I reflect on three key points that have pervaded the debate on open science, namely: (a) open access to the knowledge produced, (b) transparency in research processes, and (c) replication and reproducibility of previous research. My focus is on highlighting the need for a plural and inclusive view of science, one which is grounded on otherness assumptions.

Keywords: open science; otherness; epistemology; open data; transparency in research.
* Corresponding Author.

1. Universidade Federal da Paraiba, Programa de Pós-Graduação em Administração, João Pessoa, PB, Brazil. 2. Editor-in-chief of the Journal of Contemporary Administration (RAC).

\section{RESUMO}

O meu objetivo neste texto é apresentar um contraponto ao viés positivista que vem dominando o debate sobre ciência aberta e, assim, evidenciar alguns problemas e abrir espaço para um olhar mais plural e inclusivo sobre o assunto. Reflito sobre os três pontos centrais que marcam o debate sobre ciência aberta: (a) acesso aberto ao conhecimento produzido; (b) transparência nos processos de pesquisa; e (c) replicação e reprodutibilidade de pesquisas anteriores. Meu foco reside em conferir maior destaque à necessidade de uma visão plural e inclusiva de ciência alicerçada em pressupostos de alteridade.

Palavras-chave: ciência aberta; alteridade; epistemologia; dados abertos; transparência em pesquisa.
Cite as: Bispo, M. de S. (2022). The Impossibility of open science without otherness and epistemic plurality. Revista de Administração Contemporânea, 26(2), e210246. https://doi.org/10.1590/1982-7849rac2022210246.en 


\section{OPENING WORDS}

As the new editor-in-chief of Revista de Administração Contemporânea (RAC), I am in charge of a journal that adopted the open science policy a few years ago. Although only few journals, especially within management, have adopted this policy, I believe that we all should advocate more accessible science to everyone. However, after coming across a group of people and texts defending open science, I have realized that part of the thinking on the matter has taken (or is keen on determining) a totalizing stance. This group understands open science from a positivist perspective (and its derivations) according to which it would be possible to establish (or rather impose) a unique, closed model of how to practice open science. This stance has worried me, for the simple fact that everything intended to be total (general) ends up being exclusive. Thus, this begs the question: Is it possible to establish a perfect, unambiguous way of doing open science?

The open science movement has grown over the past two decades and is part of the contemporary scientific debate (e.g., Martins, 2020; McKiernan et al., 2016). Discussions essentially revolve around three topics: (a) open access to knowledge, (b) transparency in research processes, and (c) replication and reproducibility of previous research (Martins, 2020; Mendes-da-Silva, 2019). In short, open science seeks to make scientific work more accessible and transparent. It seems to me that there is little to no space for discussing whether science should or not move towards more accessibility and transparency. However, how we should understand 'transparency' (and an eventual insubordination to the very idea of ethics) and the 'imperative need' for replication and reproducibility of scientific research deserves a special look and a more qualified debate. My objective in this text is to present a counterpoint to the positivist bias (e.g., Aguinis, Cascio, \& Ramani, 2017; Aguinis \& Solarino, 2019; Mendes-da-Silva, 2019) that has dominated the debate on open science and eventually highlight some problems and provide a more plural and inclusive perspective on the subject. I reflect on three aforementioned key points that have pervaded the debate on open science, while also emphasizing the need for a plural, inclusive view of science (Sousa-Santos, 2008), one based on otherness assumptions (Peirano, 1999).

\section{OPEN ACCESS TO KNOWLEDGE}

The need for open access to science as a way to democratize knowledge and improve (both human and non-human) ways of life seems to be a consensus amongst scholars and has become public policy in some countries (Harnad et al., 2008; Larivière \& Sugimoto, 2018). One of the greatest difficulties in making all scientific knowledge available to anyone, especially through articles, is the journals' operating costs (Harnad et al., 2008). The scientific publishing market has circulated billions of dollars annually (Larivière, Haustein, \& Mongeon, 2015), including to have multiple professionals to meet technological needs (e.g., websites and article submission systems), editorial needs (e.g., secretary, layout, editing services) and dissemination needs (e.g., social media, attendance to scientific events). In this market, some publishers have come to profit more than companies as large as Google or Apple (Buranyi, 2017). The process is well known to scholars. Researchers investigate and write scientific articles (often without funding) and submit their manuscripts to journals that appear in the list of publishers. These manuscripts require the work of other scholars (usually from three to five) to read and review them, seeking to ensure scientific quality and providing further insights. This is the well-known peer review process. In general, neither authors nor reviewers are paid for the work they perform for publishers. However, the publishers charge significant amounts for people to have access to published articles (Edwards \& Shulenburger, 2013). This is the secret to profitability in this business (Larivière et al., 2015) and the first barrier to open science: access to published articles (Larivière $\&$ Sugimoto, 2018).

With a view to democratizing the knowledge created from research funded in their countries, some governments have also funded article processing charges so that articles do not have any costs for readers (Wingfield \& Millar, 2019). These charges can range from 2,000 to 5,000 dollars, which seems to be much higher than the actual cost of publishing a scientific article. There are also journals collecting article processing charges in two other situations. The first situation is related to what we conventionally call predatory journals (Bernardi, 2018) - they collect article processing charges that in fact represent the purchase of a space for publishing a manuscript. Many of these journals do not even have a peer review process (even though they claim otherwise on their websites). The second situation is related to serious journals that truly collect article processing charges to fund what is needed to maintain themselves and edit the manuscripts. In these cases, charges are much lower than those mentioned above and can range from 20 to 100 dollars. 
In addition to the large publishers, the predatory journals and the serious journals that collect article processing charges, there are also cases such as the one that prevails in Brazil. Several scientific journals are funded by the Brazilian universities, the federal government, state governments or associations such as ANPAD (Brazilian Academy of Management), which sponsors $R A C$, for instance. In these cases, there are no costs borne by authors or readers. Consequently, it is apparent that the name open access does not necessarily mean open, democratic and fair science. This is an extremely relevant aspect to account in any defense of open science. This involves reflecting on what it is like to do science and democratize it in a context marked by market issues (Larivière et al., 2015).

One key direction in open science should be challenging and, most likely, extinguishing rankings for scientific journals. Rankings are an instrument that feeds the scientific publishing market (Nkomo, 2009) and hinders democratization of knowledge. Determining what is 'better' or 'worse' leads to a competition for some publication spaces that end up being used for surplus value (in Karl Marx's sense). An instrument that has been used as a way to democratize knowledge through scientific articles is the preprint (Larivière \& Sugimoto, 2018). It consists of making an article available in an open repository before or simultaneously with its submission to a scientific journal. While it sounds like a good idea, it leads to two problems. The first problem is that preprints do not meet the scholars' needs to score points (publish or perish), as they are not the definitive publication and do not appear in a 'prestigious' journal. The second problem is that there are fields, such as management, in which manuscripts submitted to journals end up with a final (published) version that is very different from the original (which is the preprint) after the peer review process. Therefore, having access to the preprint does not necessarily mean (in some fields) to have access to the same content as published.

\section{TRANSPARENCY IN RESEARCH PROCESSES}

Ethics is a basic condition in scientific research (Bell $\&$ Bryman, 2007). Transparency in research processes is a way to meet the necessary requirements for ethical research (Poth, 2019). However, we cannot reduce research ethics to transparency or open-access transparency to unrestricted openness to research data. The idea of having open access to any research data may have deleterious effects and neglect some important aspects of scientific research in its multiple epistemological and methodological avenues. This is where otherness gains relevance. Otherness is a principle that supports all knowledge produced in anthropology (Peirano, 1999) and has great value in other fields such as law (Tavares-Neto \& Kozicki, 2008). Putting it simply and directly, otherness means recognizing differences without making value judgments about them. But what does otherness have to do with transparency and ethics in scientific research? The answer lies in knowing that scientific knowledge is not produced similarly across all areas of knowledge. Therefore, it is a matter of knowing and recognizing that theoretical and methodological assumptions used in fields such as natural sciences and health may not be feasible or applicable in other fields such as sociology, psychology, or management. If we are judicious about otherness, we realize that even fields such as management contain multiple possibilities for knowledge production (Paes de Paula, 2016; Sandberg \& Alvesson, 2021) despite some people's insistence that management is an 'annex' of natural sciences and their claims that Herculean efforts should be made to find general laws by developing models.

Being transparent in management research does not have to be synonymous with having all data open. This goes beyond issues of 'classified' business data, for which the mere mention that they are 'strategic' provides a 'good' justification for not making them accessible. Could it be that the very word 'strategic' carries a set of ethical conundrums for both companies and researchers? This is open for further reflection. But my point goes a little further; it refers to the ethical consequences of having any kind of data open, as already mentioned by Martins (2020). It is necessary to respect the multiple forms of knowledge production with their potential, limitations, and ethical implications (Bell \& Bryman, 2007).

To illustrate my point, I present two examples, one of female victims of sexual harassment in the workplace, and another one of cases of corruption. The following questions emerge when it comes to sexual harassment in the workplace: Is it be possible to leave the interviews open for anyone to hear or read them (even when leaving the person's name and workplace unidentified)? Would any of the interviewed victims like to read their open testimony in some data repository or find it used on some other website or social media? Could this situation cause more damage to the interviewees and legal problems for the researchers? Even if researchers followed Chauvette, Schick-Makaroff and Molzahn's (2019) guidelines and requested authorization to disclose the interviewees' data in an open repository, what would it be like if they requested the removal of their data from the repository because of the consequences of open access to their stories? Now let us turn to research on corruption: Would researchers have authorization to release particular parts of data? Wouldn't researchers and others put their own physical integrity at risk by disclosing data, as there could be, say, organized crime groups involved in some cases? 
Based on these examples and questions, I challenge the notion that open data is the main tool for transparency or even a warranty of ethical research. I am not ignoring the problems related to data fabrication and other serious operational research problems (usually in quantitative research) that must be tackled (Chawla, 2021). I am rather drawing attention to the fact that there are specifics (othernesses) that need to be respected. Otherwise, open science is heading towards a paradox: in order to guarantee transparency through open data access (without adequate relativization), it ends up excluding a set of scientific investigations that do not fit into a model that seems to be suitable only for knowledge produced in some fields, about some topics or from a given epistemological perspective. It seems sensible to advocate that transparency through open data be broadly reflected upon and adopted through levels of open data (Chauvette, Schick-Makaroff, \& Molzahn, 2019; Poth, 2019) that consider the specificities of each study.

\section{RESEARCH REPLICATION AND REPRODUCIBILITY}

Although the ideas of replication and reproducibility are well known in the scientific world, they do not represent a central issue for all types of research, especially in the humanities and social sciences. In fact, replication and reproducibility are relevant for a particular way of producing knowledge: positivist research and its derivations such as functionalism (Sousa-Santos, 2008). Acknowledging this helps us understand a set of methodological implications that have confused several researchers. Positivist-functionalist influences include the search for generalizations, the creation and testing of hypotheses, the assumptions that social phenomena are subordinate to general laws (Donaldson, 2005) and that research is only reliable if its methods are replicable and its findings are reproducible in further research. Therefore, replication and reproducibility of scientific research is an essentially positivist agenda that, once again, represents ONE (rather than THE) way of researching and producing knowledge.

From an open science point of view, it seems to me that the defense that any research should be replicable and reproducible is a short-sighted, totalizing way of determining which epistemological assumptions should be held as the parameter for different epistemological and methodological perspectives. A classic example of this debate is qualitative research. Although several scholars roughly equate qualitative research with a set of complementary methods, 'qualitative research' is in fact an umbrella term (Creswell, 2012; Stake, 2010) that houses multiple epistemological and methodological avenues. What unites the diversity of research under the umbrella of qualitative research is the type of data they use, i.e., nonnumerical or textual data (in the broad sense of text) as some authors prefer (Bispo, 2020). Therefore, qualitative research can have different epistemological orientations, including a positivist-functionalist nature.

Both researchers working primarily with quantitative research (who are predominantly positivist) and researchers working with qualitative research with a positivist-functionalist orientation assume that the replication of methods and the reproducibility of findings is important for their studies (Aguinis et al., 2017; Aguinis \& Solarino, 2019; Mendes-da-Silva, 2018). This is not a problem in itself, but it is when these researchers use the open science argument to impose their research preferences and worldview on other researchers working with other paradigms. The conundrum increases when the central argument for adopting replication and reproducibility is the understanding that qualitative research needs to demonstrate more rigor (following a positivist logic) or when it assumes that subjectivity (which is a fundamental condition for humanity and life in society) is a weakness of qualitative research. In fact, the supposed objectivity and neutrality claimed by positivists carry countless subjectivities in these presuppositions (Sousa-Santos, 2008).

My suggestion is that replicability and reproducibility should not be considered key to determining that any research or journal be classified as open science supporter, but they should be emphasized for positivist (generally quantitative) research, for which it is relevant to achieve similar findings or have statistical robustness. This, however, does not entail generalizing this process to other forms of knowledge production. Otherwise, we will be limiting the possibilities of doing science and producing knowledge, as well as excluding classical perspectives (especially those in the humanities and social sciences) such as, for instance, Wright Mills's (1975) 'sociological imagination', Alberto Guerreiro Ramos's (1966) 'sociological reduction', or even the multiple possibilities of phenomenology. All of them are present in several studies in the field of management and cannot be reduced to the ideas of replication and reproducibility.

\section{FINAL WORDS}

As I said at the beginning, I believe that making science more accessible and transparent is an important ideal sustained by open science. However, advocating open science should not entail limiting the multiple ways of producing knowledge, i.e., open science should not 
be a cage with no room for the different. I contend that we should broaden the debate on open science to find avenues that can accommodate the multiple ways of doing science and their own specificities. This requires that we recognize the otherness in the different areas of knowledge and in the various ways of researching and producing knowledge. It is urgent that open science advances in the debate on the commodification of scientific knowledge
(Larivière et al., 2015). In addition, it is necessary to ponder over very strict rules that may imply dismissing academic ethics, even under the argument of promoting ethics (as in the case of full data opening). Finally, it is pertinent to think to what extent open science canons will eventually turn open science into exclusive, closed science. We must avoid this paradox at all costs!

\section{REFERENCES}

Aguinis, H., Cascio, W. F., \& Ramani, R. S. (2017). Science's reproducibility and replicability crisis: International business is not immune. Journal of International Business Studies, 48(6), 653-663. https://doi.org/10.1057/s41267-017-0081-0

Aguinis, H., \& Solarino, A. M. (2019). Transparency and replicability in qualitative research: The case of interviews with elite informants. Strategic Management Journal, 40(8), 1291-1315. https://doi.org/10.1002/smj.3015

Bell, E., \& Bryman, A. (2007). The ethics of management research: An exploratory content analysis. British Journal of Management, 18(1), 63-77. https://doi.org/10.1111/j.1467-8551.2006.00487.x

Bernardi, S. (2018). A sombra das revistas predatórias no Brasil: Estudo mostra quantos pesquisadores do país publicam em periódicos com práticas suspeitas. Pesquisa FAPESP, (270). Retrieved from https://revistapesquisa.fapesp.br/asombra-das-revistas-predatorias-no-brasil/

Bispo, M. de S. (2020). Pesquisas qualitativas: Para além do método na pesquisa qualitativa em Ciências Sociais. In R. de C. Fazzi \& J. A. de Lima (Orgs.), Campos das Ciências Sociais: Figuras do mosaico das pesquisas no Brasil e em Portugal (pp.757-766). Petrópolis, RJ: Editora Vozes.
Buranyi, S. (2017, June 27). Is the staggeringly profitable business of scientific publishing bad for science? The Guardian. Retrieved from https://www.theguardian. com/science/2017/jun/27/profitable-business-scientificpublishing-bad-for-science

Chauvette, A., Schick-Makaroff, K., \& Molzahn, A. E. (2019). Open data in qualitative research. International Journal of Qualitative Methods, 18. https://doi.org/10.1177/1609406918823863

Chawla, D. S. (2021, July 22). 8\% of researchers in Dutch survey have falsified or fabricated data: Study of nearly 7,000 scientists also finds that more than half engage in 'questionable research practices'. Nature. https://doi.org/10.1038/d41586-021-02035-2

Creswell, J. W. (2012). Qualitative inquiry and research design: Choosing among five approaches (3 ed.). Thousand Oaks: Sage Publications.

Donaldson, L. (2005). Organization theory as a positive science. In C. Knudsen, H. Tsoukas (Eds.), The Oxford handbook of organization theory (pp. 39-62). Oxford: Oxford University Press. 
Edwards, R., \& Shulenburger, D. (2013). The high cost of scholarly journals: (And what to do about it). Change: The Magazine of Higher Learning, 35(6), 10-19. https://doi.org/10.1080/00091380309604123

Harnad, S., Brody, T., Vallières, F., Carr, L., Hitchcock, S., Gingras, Y., Oppenheim, C., Hajjem, C., \& Hilf, E. R. (2008). The access/impact problem and the green and gold roads to open access: An update. Serials Review, 34(1), 36-40. https://doi.org/10.1080/00987913.2008.10765150

Larivière, V., \& Sugimoto, C. (2018, October 24). Do authors comply when funders enforce open access to research? Nature, 562(7728), 483-486. https://doi.org/10.1038/d41586-018-07101-w

Larivière, V., Haustein, S., \& Mongeon, P. (2015). Big publishers, bigger profits: How the scholarly community lost the control of its journals. MediaTropes eJournal, 5(2), 102110. Retrieved from https://mediatropes.com/index.php/ Mediatropes/article/view/26422

Martins, H. C. (2020). A importância da ciência aberta (open science) na pesquisa em Administração. Revista de Administração Contemporânea, 24(1), 1-2. http://doi.org/10.1590/1982-7849rac2020190380

McKiernan, E. C., Bourne, P. E., Brown, C. T., Buck, S., Kenall, A., Lin, J., McDougall, D., Nosek, B. A., Ram, K., Soderberg, C. K., Spies, J. R., Thaney, K., Updegrove, A., Woo, K. H., \& Yarkoni, T. (2016). Point of view: How open science helps researchers succeed. eLife, 5, e16800. https://doi.org/10.7554/eLife.16800

Mendes-da-Silva, W. (2018). Promoção de transparência e impacto da pesquisa em negócios. Revista de Administração Contemporânea, 22(4), 639-649. https://doi.org/10.1590/1982-7849rac2018180210

Mendes-da-Silva, W. (2019). Have we been transparent enough? Challenges in replicability and credibility in business research. Revista de Administração Contemporânea, 23(5), 1-6. http://doi.org/10.1590/1982-7849rac2019190306
Mills, C. W. (1975). A imaginação sociológica. Rio de Janeiro: Zahar.

Nkomo, S. M. (2009). The seductive power of academic journal rankings: Challenges of searching for the otherwise. Academy of Management Learning \& Education, 8(1), 106112. https://doi.org/10.5465/amle.2009.37012184

Paes de Paula, A. P. (2016). Beyond paradigms in Organization Studies: the circle of epistemic matrices. Cadernos EBAPE, 14(1), 24-46. https://doi.org/10.1590/1679-395131419

Peirano, M. G. S. (1999). A alteridade em contexto: A antropologia como ciência social no Brasil. Série Antropologia, 255. Brasília: UnB. Retrieved from http://dan.unb.br/images/doc/Serie255empdf.pdf

Poth, C. N. (2019). Rigorous and ethical qualitative data reuse: Potential perils and promising practices. International Journal of Qualitative Methods, 18. https://doi.org/10.1177/1609406919868870

Ramos, A. G. (1996). A redução sociológica (3 ed.). Rio de Janeiro: Ed. UFRJ.

Sandberg, J., \& Alvesson, M. (2021). Meanings of theory: Clarifying theory through typification. Journal of Management Studies, 58(2), 487-516. https://doi.org/10.1111/joms. 12587

Sousa-Santos, B. (2008). Um discurso sobre ciências. São Paulo: Cortez Editora.

Stake, R. E. (2010). Qualitative research: Studying how things work. New York: The Guilford Press.

Tavares-Neto, J. Q., \& Kozicki, K. (2008). Do “eu” para o "outro": A alteridade como pressuposto para uma (re)significação dos direitos humanos. Revista da Faculdade de Direito UFPR, 47, 65-80. https://doi.org/10.5380/rfdufpr.v47i0.15735

Wingfield, B., \& Millar, B. (2019, April 10). How the open access model hurts academics in poorer countries. The Conversation. Retrieved from https://theconversation. com/how-the-open-access-model-hurts-academics-inpoorer-countries-113856 


\section{Authorship}

\section{Marcelo de Souza Bispo*}

Universidade Federal da Paraíba, Programa de Pós-Graduação em Administraçáo.

Campus I, Lot. Cidade Universitaria, 58051-900, João Pessoa, $\mathrm{PB}$, Brazil.

E-mail address: rac-eic@anpad.org.br

(1) https://orcid.org/0000-0002-5817-8907

* Corresponding Author

\section{Conflict of Interest}

The author have stated that there is no conflict of interest.

\section{Copyrights}

RAC owns the copyright to this content.

\section{Plagiarism Check}

The RAC maintains the practice of submitting all documents approved for publication to the plagiarism check, using specific tools, e.g.: iThenticate.

\section{SCIENTIFIC EDITORIAL BOARD AND EDITORIAL TEAM FOR THIS ISSUE:}

\section{Editorial Council}

Anielson Barbosa da Silva (UFPB, João Pessoa, PB, Brazil) Antonio Carlos Gastaud Maçada (UFRGS, Porto Alegre, RS, Brazil) Ely Laureano Paiva (FGV, São Paulo, SP, Brazil)

Rogério Hermida Quintella (NPGA/UFBA, Salvador, BA, Brazil) Valmir Emil Hoffmann (UnB, Brasília, DF, Brazil)

\section{Editor-in-chief}

Marcelo de Souza Bispo (UFPB, João Pessoa, PB, Brazil)

\section{Associate Editors}

Ariston Azevedo (UFRGS, Porto Alegre, RS, Brazil)

Carolina Andion (UDESC, Florianópolis, SC, Brazil)

Denize Grzybovski (UPF, Passo Fundo, RS, Brazil)

Eduardo da Silva Flores (FEA/USP, São Paulo, SP, Brazil)

Elisa Yoshie Ichikawa (UEM, Maringá, PR, Brazil)

Emílio José M. Arruda Filho (UNAMA, Belém, PA, Brazil)

Fernando Luiz Emerenciano Viana (Unifor, Fortaleza, CE, Brazil) Gaylord George Candler (University of North Florida, Jacksonville, Florida, USA)

Gustavo da Silva Motta (UFF, Niterói, RJ, Brazil)

Keysa Manuela Cunha de Mascena (Unifor, Fortaleza, CE, Brazil) Ludmila de Vasconcelos Machado Guimaráes (CEFET-MG, Belo Horizonte, MG, Brazil)

Natália Rese (UFPR, Curitiba, PR, Brazil)

Orleans Silva Martins (UFPB, João Pessoa, PB, Brazil)
Pablo Isla Madariaga (Universidad Técnica Federico Santa María, Chile)

Paula Castro Pires de Souza Chimenti (UFRJ/Coppead, Rio de Janeiro, Brazil)

Rafael Chiuzi (University of Toronto Mississauga, Mississauga, ON, Canada)

Sidnei Vieira Marinho (Univali, São José, SC, Brazil)

\section{Scientific Editorial Board}

André Luiz Maranhão de Souza-Leão (UFPE, Recife, CE, Brazil) Aureliano Angel Bressan (CEPEAD/UFMG, Belo Horizonte, MG, Brazil) Bryan Husted (York University, Canada)

Carlos M. Rodriguez (Delaware State University, USA)

Cristiana Cerqueira Leal (Universidade do Minho, Portugal)

Diógenes de Souza Bido (Mackenzie, São Paulo, SP, Brazil)

Erica Piros Kovacs (Kelley School of Business/Indiana University, USA)

Elin Merethe Oftedal (University of Stavanger, Norway)

Fábio Frezatti (FEA/USP, São Paulo, SP, Brazil)

Felipe Monteiro (INSEAD Business School, USA)

Howard J. Rush (University of Brighton, United Kingdom)

James Robert Moon Junior (Georgia Institute of Technology, USA)

John L. Campbell (University of Georgia, USA)

José Antônio Puppim de Oliveira (United Nations University, Yokohama, Japan)

Julián Cárdenas (Freie Universität, Berlin, Germany)

Lucas A. B. de Campos Barros (FEA/USP, São Paulo, SP, Brazil)

Luciano Rossoni (UniGranRio, Rio de Janeiro, RJ, Brazil)

M. Philippe Protin (Université Grenoble Alpes, France)

Paulo Estevão Cruvinel (Embrapa Instrumentação, São Carlos, SP, Brazil)

Rodrigo Bandeira de Mello (Merrimack College, USA)

Rodrigo Verdi (MIT Massachusetts Institute of Technology, Cambridge, USA)

Valter Afonso Vieira (UEM, Maringá, PR, Brazil)

Wagner A. Kamakura (Jones Graduate School of Business, Rice University, Houston, USA)

\section{Editing}

Typesetting and normalization to APA standards: Kler Godoy (ANPAD, Maringá, Brazil); Simone L. L. Rafael (ANPAD, Maringá, Brazil).

Frequency: Continuous publication.

Circulation: Free open access to the full text.

\section{Indexing, Directories and Rankings}

Scielo, Redalyc, DOAJ, Latindex, Cengage/GALE, Econpapers, IDEAS, EBSCO, Proquest, SPELL, Cabell's, Ulrichs, CLASE, Index Copernicus International, Sherpa Romeo, Carhus Plust, Academic Journal Guide (ABS), DIADORIM, REDIB, Sumários.org, ERIHPlus, EZB, OasisBR, IBZ Online, WorldWideScience, Google Scholar, Citefactor.org, MIAR, Capes/Qualis. 